\title{
THE RELATIONSHIP BETWEEN INDUSTRIAL ESTATE AND RURAL DEVELOPMENT (AN EVALUATION OF PJT'S CSR)
}

\author{
Genoveva1 $^{1}$, Anastasia Purwanti ${ }^{2}$, Kevin Pratama ${ }^{3}$ and Aris Akbar ${ }^{4}$ \\ 1,2,3,4 Management Study Program, School of Business, President University \\ Corespondent : genoveva@president.ac.id
}

\begin{abstract}
The existence of industrial estates should have a positive impact on the surrounding community. But not all people can feel the positive impact of the existence of industrial estates. The industrial area in this study is Jababeka Cikarang industrial area where there are more than 1600 companies. One large company, PJS, which has been carrying out corporate social activities (CSR) for more than 5 years in collaboration with President University, conducted research to find out the effectiveness of the CSR they have done, especially in 3 villages located in ring 1 (the location closest to the area industry). The study was conducted with qualitative methods, namely in-depth interviews with villagers who were representatives of each village as many as 35 people. The questions were tested for validity and reliability with triangulation, namely the PJS company partners and the Village Heads from the 3 villages that became the research object. From the tri buttom line approach the results of the research show that both socially (people), environment (planet) and economic (profit) have not had a significant impact on the villagers.
\end{abstract}

Keywords : Industrial Estate, Rural Development, Corporate Social Responsibility

\section{Background of the CSR}

These days, in the world of business, each organization vies for each other just to get by in the general public. This globalization time is the highlight for the organization to dependably know about the significance of their surroundings in order to create and make certain a well-living environment with each other. Several problems and issues facing most rural areas including poverty, health problems, high rate of unemployment combined with unskilled labor work force, and bad education background are most acute in rural areas. This is not only because of shortage of material resources but also because of defects in planning process and society pattern.

In such issues, Indonesia can possibly meet these difficulties in rural areas. Knowing the facts, the endeavors of Governments may not be sufficient to give fundamental monetary or nonmonetary supports to its people. It is by and large progressively perceived that advance and welfare of a general public is not the obligation of the government alone, as well as numerous more partners should be included to achieve the goal for equal improvement. The corporate has a vital part to play in guaranteeing the development of its surrounding to make sure that society life will not be left behind. Therefore, corporations must consider themselves as an integral part of society and accordingly in the form of CSR (Corporate Social Responsibility). According to Amidu et all (2015), Wang (2011) in his analysis defines that CSR as a tool to keep sustainability and social obligations like economic, legal, ethical and discretionary responsibilities to specific surroundings.

In this research, PJT CorporateTbk, acting as the largest industrial estate in Southeast Asia is considered as playing a vital role in advancing the society life of its surrounding, yet truth to be told, as specified by the existence of PJT Corporate would not give any significant help due to unsuitable CSR program that has been given to several rural areas. In this research, PJT Corporatewould like to administer the use of CSR to help the advancement of its surroundings by providing CSR program that is purely needed by the chosen rural areas. Therefore, the researchers used 3 rural areas in Cikarang which are Mekarmukti, KarangBaru, and Jayamukti as the object of the research. 
In such a situation, CSR can be seen as a tool whose aim to basically ensure the quality of its surrounding by looking at the current economic background, social or environmental outlook. PJT Corporate legitimately needs to be able to take some actions by providing such great CSR Program, yet suitable for the development of the chosen rural area in order to give beneficial program for the surroundings. In accordance with his research, Pradhan \& Ranjan (2010) also stated that CSR has a positive impact in advancing the society life and an organization must be able to administer the use of CSR at the right time and at the right place.

Based on the data received from interviewing the head of the village coordinator in 3 villages, it can be concluded that there are several issues spotted from the 3 chosen villages. The problems are as follows;

1) The quality of life is considered relatively low because of some reasons such as the unavailability of clean water, the high rate of unemployment combined with unskilled labor workforce, poor educational background (only ranging from junior high until senior high school), unproductive surroundings, etc.

2) The infrastructures in most areas are still in bad shape or condition, proven by its bad street all the way through, the damage in certain areas which is still undone, the availability of some public facilities such as hospital and other things are low.

3) PJT CorporateTbk. currently does not give any significant support for the development of the chosen 3 rural areas.

\section{Principles of Social Responsibility}

According to David and Aras (2008) there are three principles of corporate social responsibility, which consist of:

1) Sustainaibility

Since there are a lot of resources that cannot be regenerated, it is now a must for corporations to manage the use of resources well, especially for no longer utilizing the resources which cannot be regenerated. Those kind of resources, especially for the natural ones such as the raw materials would not be available in the future if they had been exploited at the present. Therefore, it is very important to concern of this aspect to also maintain the sustainability of the corporation. As part of the social and economic system, corporations should take into account this aspect not only for the sake of the corporations themselves, but also for the well-being of the society in the long-term future.

2) Accountability

It is very important of an organization or firm to recognize the effects that might be caused by its action towards the surrounding society and environment. Hence, an organization must be responsible for all actions which have been done to bith the internal and external parties. To be more specific, it is very necessary for this organization to provide a report to those parties. This report must consist of information which are understandable, relevant, reliable, comparable, and consistent.

3) Transparency

In relation with the two previous principles, transparency here is about providing a real information to all of the stakeholders of the organization. This is very important especially for the external stakeholders. All information should be provided in details and use the appropriate mechanism of the report framing. 


\section{The Triple Bottom Line}

One of the most significant innovation of corporate social responsibility field is the concept develed by Alhadd (2015) which is called as "The Triple Bottom Line" concept. This concept explains the importance of taking $3 \mathrm{P}$ into account in order to build a sustainable corporation. A corporation should not only concern about profit, but also people and planet. People aspect here refers to the positive contribution that should be given by the corporation to the surrounding society, as well as actively participate in maintaining the environmental sustainability (planet).

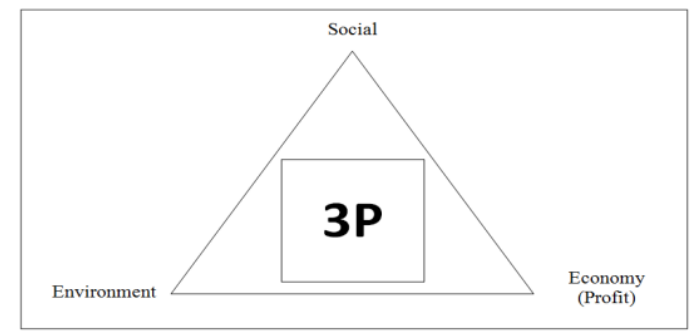

Source: Alhadd, 2015

This triple bottom line concept has been positively responded by a lot of people from various background since it has combined the two important dimensions which are social and economic motives, in which it involves both the goals as well as the responsibility of the corporation itself as it illustrates the integral connectivity between those three elements; people, planet, and profit.

\section{Corporate Impact}

According to Hadi (2011), the existence of corporation in the middle of an environment has a direct and indirect impact towards the external environment (community). In addition, according to the Global Reporting Initiative (GRI) as cited in Hadi (2011), it was stated that a corporation has an impact to the stakeholders in various aspects, including economic, social, and environment. In terms of economic, there are three main aspects that can be focused on to assess the level of accomplishment and measurement of impact and economic benefits, they are:

1) Economic performance, means that the existence of a corporation in the middle of an environment has an impact towards the swift of economy, positively or negatively.

2) Market presence, related with the interaction of corporation towards a certain market.

3) Indirect economic impact, refers to the indirect economic impact which are caused by the transactions of the corporations. 


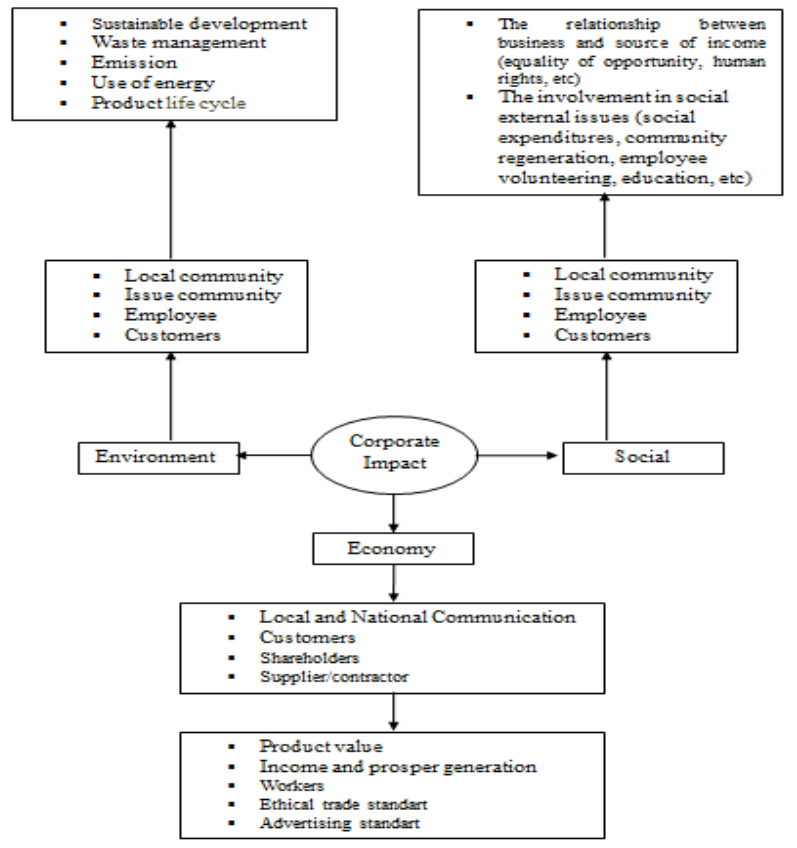

Source : Andriof \& MacIntosh in Hadi (2011)

\section{METHODOLOGY}

This research applies the qualitative approach in solving the research question. In light to the objective of research, the high number of samples is required to give a varied perception regarding the research with hope to uncover the truth behind this problem. The researchers believe in using qualitative research because the research involves a wide range of samples from various background.

\section{Data Collection Method}

The primary data will be collected using in-depth interview with the selected samples and the secondary data will be collected through literature. The interview will be adapting the unstructured interview which is deemed as proper way to use in approaching research objective as it is supposed to gain a deeper understanding of each area where the samples live. The unstructured interview is most appropriate in handling a broad matter or phenomenon therefore, the researchers believe in using this method of data collection in addressing the research objective regarding PJT CSR program and its influence to the society. All of the primary data gathered from the sample then the secondary data will be used to support the primary data in their explanation.

\section{Population and Sample}

The population of this research is the people who live in the area of 3 villages which are Mekar Mukti village, Jaya Mukti village, and Karang Baru village. Based on the population, the sample that is appropriate to answer the research question is the elders from each small parts of the village (ketua $R W$ ) and also religious leader (pemuka agama). It is actually possible to use the lower rank position (RT) as the sample but the size of RT is too small and it is highly expected to find a similar problem within RT territory. The total sample size is 35 respondent, they are 11 from Mekar Mukti Village, 10 from Jaya Mukti Village and 14 from Karang Baru Village. 


\section{Triangulation}

Qualitative research relies on triangulation to show and improve the accuracy of the research. Based on Ndaru \& Syombua (2015) triangulation is a method that will check the information in order to give a valid and reliable result in data collection. Triangulation unified the views from different side of respondents. In this research, the respondent of interview came from different background. The different in economy, education, geographical, and social status will differ the answer of each respondent. The study is believe to be exact because the respondent come from variative sources and individual. By combining many different opinion will create an exact and clearer view regarding the reality, Berg (2009).

\section{Research Analysis Model}

Researchers will be find the influence of PJT Corporate CSR on society and what are the solution (the future activities) for the society if there is the positive or negative impact.

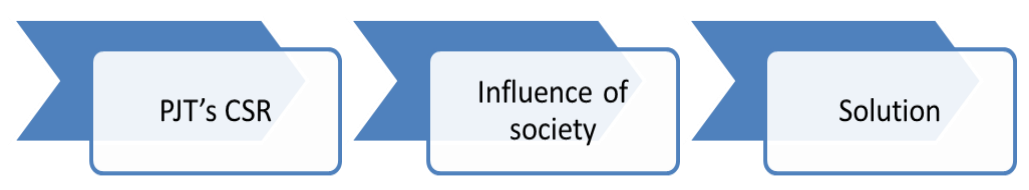

Source : create by researchers, 2018

\section{RESEARCH FINDINGS AND DATA ANALYSIS}

\section{Mekar Mukti Village}

Mekar Mukti is a village located in Cikarang at main street of Cibarusah to be precise. This village also falls under the administration of Cikarang Utara district. This village is one of many villages located at the vicinity of Jababeka industry estate. The government and administration of the village is being handled by the village chief. This village is located at the riverbank of Kalimalang.

Mekar Mukti village is one of many villages that is directly in interaction with PJT Corporate but, there are many who complain about the lack of local workforce being absorbed by the company. Based on our respondents the villagers from Mekar Mukti many of them are working as a laborer for construction, Ojek, farmer, freelancers, workshops, and a minimarket owner many of this are only for temporary.

This village are having a rather good infrastructure in water provider, and electricity for daily life, but there are several bad points in the village infrastructure. Some of the respondents reveal several facts regarding flood, bad waste management, the unavailability of medical provider. The lacking of several basic needs put the villagers in a bad shape of living in their area.

The education state of Mekar Mukti are not showing a good indicator as well as the infrastructures. Mekar Mukti villagers are mostly the ones graduated in junior High school, and high school. These state of education level are not showing a good opportunity for the people to improve their unemployment rate because company are not usually hiring employee with low education level except for the hard labourer.

Mekar Mukti village are not in a proper condition for a standard living. Flooded river, and waste that's keep pouring down to the village area destroy the environment around the village which 
worsen the living condition in Mekar mukti. The living condition, education, work environment are not giving a positive result for the development of the villagers life for the future. Therefore the condition of Mekar mukti is not in its best shape and needed a proper allocation and effort to build it to be a better place.

\section{Karang Baru Village}

Karang Baru is a village located at Cikarang Utara around main street of Fatahillah and R.E Martadinata street. This village has a similar condition with the previous village though in different manner. Karang Baru is also located near a river although it is different than Kalimalang which is the source of water near Mekar Mukti village.

Karang Baru has a different situation than Mekar Mukti workers whom most inhabitants work as farmers. In Karang Baru there are no agriculture land to be cultivate therefore, there are no farmer there, but mostly the villagers are working as peddlers, laborers, and shop owners there are also some villagers who work as Oncom makers who sells their product at Cikarang market. The laborers are mostly only for a single work not a permanent worker hence, they only work for a certain time period.

Infrastructure is also one of the concern in Karang Baru village especially in their street lightings. Many of our respondents also complaint about the water in the river near their area being polluted by the nearby factory which already cause several children being contaminated by dangerous illness. Another complaint from our respondents is about the village accessibility being disrupt.

Karang Baru village has a very low average education level among its people inside the village administrative area. Among its people Karang Baru has most people graduating only from junior high school grade and only very few who are able to continue their study into high school level. Many respondent are saying that they are facing a considerable difficulty in reaching school location because the distance between their place and school building are very far away. Therefore many of the children from Karang Baru cannot continue their study further from junior high school into high school.

Inevitably Karang Baru is not in the correct position to grow further and become independent. People from Karang Baru do not have a stable income in their occupation as their occupation are freelances, oncom maker, and hard labor which possess a highly unstable income. Involving the right facility or infrastructure would do well to support the people of Karang Baru to grow though, the current infrastructure in Karang Baru does not support their people.

\section{Jaya Mukti Village}

Also as a part of the North Cikarang area, the area of Jaya Mukti village is separated by the Kalimalang river, in which the coverage area is located along the riverside of Kalimalang. Geographically, it is located on the highest land of Cikarang area which made it safe from flood even though it is located along the side of Kalimalang river. In addition, the coverage area is on the frontier of Jababeka and Lippo Cikarang territory, the two largest property developer at Cikarang.

Despite of the fact that this village is located at the frontier of these two largest property developer at Cikarang, the economic situation of this village varies between each sub-district. Similar to the other previous villages, most of the locals only work as ojek, farmers, while the 
rest are still unemployed and found it difficult to be employed by the companies located around Cikarang area especially for those companies which are the tenants of Jababeka. However, there is also one of the sub-districts whose most inhabitants had been employed by the companies around Cikarang due to the effort done by the sub-district head, especially the advantage of his broad networking with people working at those companies.

Moving to the discussion of infrastructure, overall access and physical situation of the village is quite fine yet still needs a lot of improvement. The basic necessity of RW 01 such as clean water has been fulfilled, while at RW 02 the inhabitants still have the salty water as they have not been reached by the PDAM and the main source of water came from the draw well. In addition, in RW 04 still needs the construction of public toilets as most of the inhabitants still do not have their own toilets which indirectly forced them to use the river as the main place for public bathing, washing and toilet facilities (MCK).

Talking about the education level of the local inhabitants at Jaya Mukti, it is quite similar to the other previous villages in which most of them are only the graduates of junior and senior high schools and there are very limited number of them who are pursuing the higher level of education (diploma or bachelor degree). However, most locals had found it easy to reach the nearest public schools due to the availability of public transportation. Yet, the main problem is the same with most people in the other villages which is related to financial condition.

Located higher compared to the other two villages, Jaya Mukti has the advantage of being secured from the flood even though it is located along the side of Kalimalang river. However, there are still a lot of problems occurred in the village especially due to its village chief who is considered as not very concerned to the situation of the villagers (based on the perception of the villagers themselves). One of the sub-districts could be considered of having quite good economic development as most of the locals have been fully-employed by the companies yet the rest sub-districts still found a lot of obstacles both in looking for jobs and also starting a small business. Due to this fact, it is very important to optimize the function of the village chief and surely the good cooperation between all of the stakeholders to improve the condition of the village to solve the problems faced by them.

\section{CONCLUSION AND RECOMMENDATION}

\section{Conclusion}

In accordance with the analysis in the previous, it clarifies that the chosen 3 villages which are Mekarmukti, Karang Baru, and Jayamukti have not gotten any significant help in the form of tibuttom line approach : social (people), enviroment (planet) and monetary (profit) from PJT Corporate.

\section{Recommendation}

\section{1) For Mekarmukti Village}

\section{a. Need of Waste Management Training}

Trash may be the major problem facing Mekarmukti Village, on the other, the way Mekarmukti manage the trash is what matters. PJT Corporate. must be able to provide Waste Management Training for Mekarmukti Village in order to manage waste and send them to a better disposal.

\section{b. Job Vacancy}

The people of Mekarmukti are expecting job vacancies from PJT. In that occasion, PJT Corporate has to provide more job vacancies and deliver the information well to the village. 


\section{2) For Karang Baru Village}

\section{a. Need of Waste Management Training}

Karang Baru village is also experiencing waste of overproduction. Therefore, PJT CorporateTbk. also must be able to provide Waste Management Training for Karang Baru Village in order to manage waste and send them to a better disposal.

\section{b. Infrastructure}

The most areas at Karang Baru village are not well equipped with better infrastructure especially for Street Light in which making the whole area looks dim. Thus, PJT CorporateTbk. is expected to build some Street Lights in the area of Karang Baru Village.

\section{c. Job Vacancy}

The same as Mekarmukti Village, The people of Karangbaru are also expecting job vacancies from PJT CorporateTbk.. In that occasion, PJT CorporateTbk. has to provide more job vacancies and deliver the information well.

\section{For Jayamukti Village}

\section{a. Job Vacancy}

The people of Jayamukti are experiencing high rate of unemployment. That also concludes that the productivity at Jayamukti village is considered weak compared to other villages. In that occasion, PJT CorporateTbk. has to provide more job vacancies and deliver the information well.

\section{b. Infrastructure}

Jayamukti village can be considered weak in providing a better facilities to its people especially for public bathing, washing, and toilet facilities. Therefore, PJT CorporateTbk. is expected to build public bathing, washing, and toiler facilities in the area of Jayamukti Village.

\section{c. Monetary and Nonmonetary Supports}

Many of people at Jayamukti village are considering to be entrepreneur, yet on the other hand, they are not equipped with skills and capital. Therefore, PJT CorporateTbk. is expected to give monetary supports for the people at Jayamukti Village and also give them training to start up a business.

One of the issues attacking the chosen 3 villages is the mindset to change for better quality of life for being independent. Here the researchers recommended the changing mindset model (developed by McKinsey) whose goal to improve the development of the villages to become independent (Friga, 2018) by being able to open their own business (entrepreneurial spirit) and increasing their skills for getting the job opportunity.

Researchers concluded the conclusion and recommendation in TOWS matrix as the follow : 


\begin{tabular}{|c|c|c|}
\hline $\begin{array}{l}\text { Mekar Mukti Village } \\
\text { Karang baru Village } \\
\text { Jaya Baru Village }\end{array}$ & $\begin{array}{l}\text { Strengths: } \\
\text { - Strategic location (the } \\
\text { ring } 1 \text { of Jababeka } \\
\text { industrial area) } \\
\text { - Productive age } \\
\text { population }\end{array}$ & $\begin{array}{l}\text { Weaknesses: } \\
\text {-Less qualified of human } \\
\text { capital } \\
\text {-Low interest to starting } \\
\text { independent business } \\
\text {-Bad infrastructure }\end{array}$ \\
\hline $\begin{array}{l}\text { Opportunities: } \\
\text {-A lot of help from } \\
\text { surrounding companies } \\
\text { by CSR programs }\end{array}$ & $\begin{array}{l}\text { S-O Strategies: } \\
\text { - Integrated CSR program } \\
\text { from surrounding companies } \\
\text { - Provide special CSR for } \\
\text { productive age population }\end{array}$ & $\begin{array}{l}\text { W-O Strategies : } \\
\text { - Provide training for } \\
\text { productive age population } \\
\text { (increasing their skils) } \\
\text { - Provide training \& incentive } \\
\text { for entrepreneurship } \\
\text { programs } \\
\text { - Improve the infrastructure }\end{array}$ \\
\hline $\begin{array}{l}\text { Threats: } \\
\text { - A lot of newcomers and } \\
\text { expatriates who have } \\
\text { higher education } \\
\text { - Losing the farmer jobs } \\
\text { cause of building } \\
\text { construction }\end{array}$ & $\begin{array}{l}\text { S-T Strategies : } \\
\text { - Job opportunity for } \\
\text { productive age population } \\
\text { - Changing the mindset of } \\
\text { farmers }\end{array}$ & $\begin{array}{l}\text { W-T Strategies : } \\
\text { - Provide job opportunity } \\
\text { from foreigners (exp.home } \\
\text { assistant) } \\
\text { - Building construction with } \\
\text { better infrastructure }\end{array}$ \\
\hline
\end{tabular}

\section{REFERENCE}

Alhadd, Hanan. (2015). Triple Bottom Line and Sustainability: A Literature Review. Business and Management Studies. Vol. 1. No.2. September 2015. Pp.1-6.

Aminu, Hamidu Ahma; Harashid, Haron Md. And Azlan, Amran. (2015). Corporate Social Responsibility: A Review on definitions, corecharacteristics and theoretical perspectives. Mediterranean Journal of Social Science 2015. Vol.6 (4): pp. 83-95

Andriof, Jorg and MacIntosh, Malcolm. (2001). Perspectives on Corporate Citizenship. Publisher: Routledge; 1 edition.

Aras, Güler and Crowther, David. (2008). Governance and Sustainability: An Investigation Into The Relationship Between Corporate Governance and Corporate Sustainability. Emerald Insight : Management Decision. Volume 46. Issue 3. Pp 443-448.

Berg, Bruce L. (2009). Qualitative Research Methods for the Social Sciences, 7th Edition. Long Beach : California State University. Pearson.

Friga, Paul N .(2018). The Mckinsey Engagement : A Powerfull Toolkit For More Efficient And Effective Team Problem Solving. USA : McGrow-Hill Company.

Hadi, Nur. (2011). Corporate Social Responsibility edisi Pertama.Yogyakarta : Graha Ilmu.

Ndanu, Mwaniki Celestine \& Syombua, Mue Jacinta. (2015). Mixed Methods Research: The Hidden Cracks of the Triangulation Design. General Education Design. Vol. 4. 1ssue 2. Pp. 46-67. 
Pradhan, Sanjay and Ranjan, Akhilesh. (2010). Corporate Social Responsibility in Rural Development Sector: Evidences fromIndia. School of Doctoral Studies

(European Union) Journal -2. pp. 139-147.

Wang, Lei. (2011). Factors Affecting Perceptions of Corporate Social Responsibility Implementation: An Emphasis on Value. University of Helsinki : dissertation 